\title{
Już nie Diels-Kranz (DK), lecz Laks-Most (LM)
}

Laks, A., Most, G., Early Greek Philosophy, 1-9 vols., Cambridge MS 2016 (Loeb Classical Library 524-532).

Laks, A., Most, G., Les débuts de la Philosophie, des premiers penseurs grecs à Socrate, Paris 2016.

\section{LIVIO ROSETTI / Perugia /}

Obszerny zbiór tekstów i świadectw o 'filozofach' przedsokratejskich, który od dawna nosi miano Diels-Kranz (DK), ukazał się w 1903 roku i bywał uwspółcześniany aż do 1952 roku. Od razu stał się dziełem, które zyskało rzadki przywilej przetrwania wielu prób selektywnych przeróbek, które następowały do niedawna (ostatnie: D.W. Graham, The Texts of Early Greek Philosophy, Cambridge 2010; J. Pórtulas, S. Grau, Saviesa grega arcaica, Barcelona 2011; J. Mansfeld, O. Primavesi, Die Vorsokratiker, Griechisch-Deutsch, Stuttgart 2012). Nie przypadkiem zresztą, choć przedstawiając sobą nieuchronne niedogodności (minęło już ponad sto dziesięć lat, powstała góra publikacji i znacząca liczba nowych danych zaistniałych w międzyczasie), dzieło to zgodnie uznane jest za wzorcowe w swej dokładności i wiarygodności 'w ramach ludzkich możliwości'. 
Sytuacja zmieniła się jednak wraz z wydaniem dziewięciu nowych tomów małego formatu Early Greek Philosophy (część Loeb Classical Library, cennej kolekcji greckich i łacińskich tekstów, tłumaczonych na angielski i komentowanych, publikowanych na Harvardzie), a także paralelnie w jednym wielkim tomie Les débuts de la philosophie, opublikowanym niedawno (2016) w Paryżu przez wydawnictwo Arthème Fayard. W obydwu tych edycjach doboru tekstów i informacji dokonali André Laks, emerytowany profesor Sorbony, oraz Glenn W. Most, profesor w Scuola Normale w Pizie i w Uniwersytecie Chicago, przy współpracy Gérarda Journée, Leopolda Iribarren, Davida Levystone, i innych. Harwardzka edycja w dziewięciu tomach osiąga niemal 4200 stron; ta w języku francuskim liczy tylko ponad 1650 stron, lecz wydana została w innym formacie. Wraz z tym dziełem sytuacja się zmieniła, gdyż teraz spełnione zostały warunki, by cytować LM zamiast DK, nawet jeśli przez kilka lat nieodzowne będzie podawanie obok numeracji LM również tą DK.

Wprawdzie we Słowie wstępnym Laks i Most stwierdzają, że „obecny zbiór, mogąc być użyteczny dla specjalistów, ma również na celu przedstawienie szerszej publiczności dostępnych informacji dotyczących początków filozofii greckiej”, lecz jest to tylko wyraz respektu i skromności wobec okazałości poprzedniego dzieła Dielsa-Kranza. Wszelako co do zamiaru piszącego, podobna deklaracja nie może zmylić nikogo.

Dzieło zawiera, jeśli dobrze przeliczyłem, prawie 3.60o tekstów, z których każdy podany jest w języku oryginalnym (greckim, łacińskim, hebrajskim, syryjskim, armeńskim i arabskim), wraz z odpowiednio dobranymi adnotacjami dotyczącymi wątpliwości co do odtworzenia tekstu i związanej z tym tradycji, która podług normy już ustalonej, nie ogranicza się tylko do fragmentów. Są to teksty, które dotyczą Talesa, Anaksymandra, Anaksymenesa, Pitagorasa i pitagorejczyków, Heraklita, Parmenidesa, Zenona, Empedoklesa, Demokryta, Protagorasa, Gorgiasza itd. Dziewiędziesiąt rozdziałów edycji Dielsa-Kranza zostało tutaj ograniczonych do 43 (do 30 nie licząc sofistów), natomiast Graham ograniczył się do wyboru tylko 20, Pórtulas i Grau do 26 (lecz jedynie do okresu od początków do Parmenidesa), Mansfeld i Primavesi do 12 (rachunek schematyczny, którego w tym miejscu może warto nie 'uścślać'). Autorzy uznani za pomniejszych (Petron, Ikkos, Menestor, Kleidemos, Idaios, itd.) nie zostali ujęci w LM i jest to wybór zasadny. W zamian Laks i Most zaczynają od szerszej selekcji tekstów Homera i Hezjoda, Teognisa, Pindara i innych poetów epoki archaicznej, a kończą na analogicznej panoramie testów tragików i komików - to dwie ważne nowości względem DK, a także względem większości podobnych zbiorów. Po mistrzach poezji archaicznej następują ci 'zwyczajowi': Tales, Anaksymander itd., natomiast po Heraklicie proponuje się obszerną i wyartykułowaną sekcję o Pitagorasie i pitagorejczykach, która ze swymi 190 stronicami w edycji francuskiej stanowi najobszerniejszą część w całym dziele (drugą co do wielkości jest część dotycząca Empedoklesa obejmująca 16o stron). Pośród nowych haseł figuruje także kilka pożytecznych sekcji: jedna o doksografach i ‘sukcesjach' (wielkie dzieło historiograficzne napisane w epoce hellenistycznej i zachowane w dość niepewnym kształcie), druga to obszerny wybór tekstów lekarskich, a trzecią to Papirus z Derveni (ten ostatni 
przy wydatnym wkładzie włoszki Valerii Piano): dobór tych tekstów należy uznać za nader szczęśliwy.

W przedstawieniu przedsokratyków Laks i Most wychodzą więc od Dielsa-Kranza (nie do pomyślenia byłoby inne podejście), lecz czynią to po przemyśleniu materii od początku do końca i z wielką swobodą intelektualną. Kiedy to tylko możliwe, dla każdego autora źródła podane są w trzech sekcjach: $\mathrm{P}$ - o jego osobie i danych biograficznych, $\mathrm{D}$ - o jego naukach, $\mathrm{R}$ - o jego echach i późniejszych dyskusjach. Pokaźną objętość mają sekcje R dotyczące Heraklita, Empedoklesa i Demokryta, lecz zadziwia także znacząca objętość rozdziału poświęconego Melissosowi. Dużą zaletę - którą wszyscy docenią stanowi decyzja o ułożeniu całości podług dobrze zorganizowanej serii podtytułów, które umożliwiają konstrukcję różnych poziomów, i układu pojedynczych rozdziałów, i pozwalają na utworzenie znacznej liczby małych jednorodnych grup informacji. W ten sposób ten, kto poszukuje jakiegoś szczególnego zagadnienia, ma ułatwione zadanie, zwłaszcza że każdy rozdział otwiera spis tytułów użytecznych dla scharakteryzowania poszczególnych grup i podgrup dokumentów. Formuła ta funkcjonuje dobrze i ma tę zaletę, że wprowadza pewien porządek pośród informacji - pozwala nie tylko wstępnie zorientować się wśród informacji, lecz przede wszystkim uwidocznić komponent encyklopedyczny dzieł wielu spośród przedsokratyków (np. Parmenidesa).

Wybór uprzywilejowania informacji nie przeszkadza utworzeniu efektów kolateralnych; przede wszystkim uzasadnia prezentację fragmentów i świadectw na podstawie przedmiotowej, wyszczególnienie fragmentów tłustym drukiem, ale służy także umieszczeniu wielu tekstów w kontekście, np. tych, które wtrącają dany fragment (zamiast przytaczać je, jeśli warto, w obszarze sekcji R). Ten ostatni wybór jest właśnie takim wyborem, wyrazem pewnego kryterium, choć nie jest pozbawiony kontrpropozycji. Dla przykładu, oczekiwałbym szerszego uwzględnienia (w sekcji R) kontekstów, które Laks i Most pomijają, gdy chodzi o prezentacje jakiegoś fragmentu.

Druga doniosła innowacja jest całkiem innej natury i dotyczy obecności sekcji o Sokratesie. Od ponad wieku wszyscy nauczyliśmy się mówić o filozofach przedsokratejskich i przez to oddzielać Sokratesa od nich wszystkich, wiedząc nawet, że działał on w tym samym czasie, co postacie ogólnie uznawane za sofistów, a nie po nich samych. Otóż Laks i Most ośmielili się uczynić to, czego - o ile się nie mylę - nikt wcześniej nie uczynił: wstawili do swego zbioru także rozdział zadedykowany Sokratesowi. Wybór wydaje się być kuriozalny, gdyż czyni z Sokratesa... przedsokratyka (w istocie przedplatonika, którym faktycznie był), a na swój sposób jest również wybuchowy, ponieważ pozwala na przedstawienie Sokratesa w kategoriach filozofii V wieku przed Chr., co zresztą jest słuszne, a nie w kategoriach Platona i jego współczesnych. To tak, jakbyśmy wyzwolili się z obowiązku pojmowania Sokratesa na podstawie wielu setek stron napisanych z dystansu kilku dekad od jego śmierci. Mam wrażenie, że na tej drodze Laks i Most stworzyli tylko początkowy jej fragment, pierwszy odcinek, albowiem selekcja źródeł opiera się zbytnio na tekstach platońskich, przemilcza zaś zupełnie świadectwa o oskarżeniach ze strony Polikratesa, nie docenia zupełnie świadectwa Ajschinesa ze Sfettos i Fedona oraz nazbyt oszczędnie korzysta z tekstów Ksenofonta. 
Wiadomo jednak, że najtrudniej jest rozpocząć, a po postawieniu pierwszego kroku o wiele łatwiej będzie poczynić kolejne. Sądzę w sumie, że ta szczególna innowacja ma na celu stworzenie efektu o szczególnym znaczeniu, nie z tego powodu, iż Laks i Most wybrali czy poopuszczali cokolwiek, lecz przez jasność, jaką ich wybór zapewnia wymogowi wkomponowania Sokratesa w poczet nie-filozofów V wieku, co - w konsekwencji - pozwala dostrzec, na ile jest on reprezentatywny, zwłaszcza dla innej epoki (tej ich autorów) łącznie z dialogami sokratejskimi.

Sygnalizuję też obecność dwóch dokładnych apendyksów, zwłaszcza informującego o ponad dwustu osobach, które wchodzą na scenę jako autorzy (tych, których się cytuje) albo jako osoby (o których się pisze). Szkoda, że dobór osób, o których się informuje, jest zbyt selektywny, oraz nie wskazuje się stron, na których się pojawiają. Drugi zaś apendyks to snadne glosarium, zawsze użyteczne, a są jeszcze inne apendyksy.

W każdym razie, rezultatem wielkiego przełomu nie jest żaden $\mathrm{z}$ tych dotąd podanych: jest nim dojście do celu tak ambitnego, osiągnięte przy utrzymaniu pod kontrolą tak imponującej masy dokumentów.

Defekty? Skłonny jestem powiedzieć: jeśli są takie, są dobrze ukryte i trzeba je wynaleźć. Zapewne są takie, bo po prostu czymś ludzkim jest ich występowanie, a zależy to również w dużej mierze od niemożliwości spełnienia życzeń różnych czytelników. Poważny brak dotyczy niewątpliwie indeksu źródeł, lecz logiczne jest oczekiwanie, że da się temu zaradzić, kiedy zostanie udostępnione drugie wydanie. Faktycznie, kiedy ktoś stara się ustalić, czy jakiś tekst został uwzględniony, czy pominięty, staje z konieczności przed trudnym zadaniem, nawet jeśli można zawsze liczyć na tabelę konkordancji między DK i LM, która wypadła całkiem dobrze.

Jeszcze w materii opuszczeń (nie będę wspominał o wyborach poczynionych w zakresie ustalania tekstu i tradycji) - można by dojść do pewnej znaczącej ich listy, zważywszy na skłonność wydawcow do ograniczania rozdziałów. Tutaj tylko pewne zasygnalizowanie dotyczące dziedzin bliższych recenzentowi.

W przypadku rozdziału 5 o Talesie brak wzmianki, jaką poczynił poeta z Lesbos, Alkajos, chociaż Diels-Kranz podaje tę informację w DK 11 A 11a, jako też o tytule sophos, którym miasto Ateny miało uhonorować Talesa 'przed' uformowaniem grupy siedmiu mędrców. Chodzi wszak o detale, które mówią o sławie osiągniętej przez osobę w życiu i, co się tyczy Aten, polityki kulturowej około roku 580 przed Chr. W tym czasie dziedzina 'odkryć astronomicznych' jest szczególna w zakresie miar przestrzennych, ale zostaje podana tylko jedna informacja dotycząca pór roku (5R25), natomiast szczegół nie mniej znaczący o interwale czasowym między jesiennym zrównaniem nocy i dnia i zachodem Plejad znajdujemy w 5R21, a zatem nieco poza swym miejscem. Byłoby jednak możliwe (i pożądane) podkreślenie wzmianki dotyczącej nierównej długości interwałów czasowych (między przesileniem dnia z nocą i zrównaniem dnia z nocą, co implikuje umiejętność określenia dokładnej daty jednych i drugich), co zostaje niejako zagubione w $5 \mathrm{R} 16$, tekście traktowanym jako informacja dotycząca Słońca. Co zaś tyczy się jego „nastawienia wobec życia” (przy jednym z podtytułów, który figuruje na s. 140 edycji francu- 
skiej), powinno się uwzględnić pogląd Talesa na grzebanie ciał - informacja obecna w DK 11 A 13 (= Th 318 Wöhrle).

W rozdziale 19 o Parmenidesie uderza pominięcie jego słów we fr. 20 Cerri (pochwała Ameiniasa, o której mówi Boecjusz), choć nie jest czymś rzadkim, że autor okresu zwanego archaicznym postanawia kogoś uhonorować (np. Pausanias wspomniany przez Empedoklesa). To, że zostaje to pominięte w innych zbiorach, między innymi Grahama, Pórtulas-Grau i Mansfeld-Primavesi, nie jest dobrym powodem, by takie świadectwo ignorować. Ponadto, odnotowując neologizmy odosobnione, choćby słowa alogon, pseudophanēs et hudatorizon, chcielibyśmy widzieć je jako podane tłustym drukiem, niezależnie od poglądu wydawców o efektywnym ojcostwie tego czy tamtego neologizmu.

Rozdział 20 o Zenonie wydaje się zbyt krótki w porównaniu ze zbiorem wydanym przez H.P.D. Lee w roku 1936 (Zeno of Elea, s. 12-63), tym bardziej, że sam Lee okazał się zbyt selektywny do tego stopnia, że na próżno szukałoby się np. odpowiednich passusów (które nie są ani rodzajowe ani pleonastyczne) De lineis insecabilibus Pseudo-Arystotelesa, passusów, które zostały pominięte także przez LM. Inne pominięcie dotyczy tekstu sygnalizowanego, jak wiadomo, przez John Dillona w roku 1974, w którym Proklos jednoznacznie podaje, że Zenon mówił o antypodach, poświadczając, że Zenon mógł stosować ten termin jako już ustalony, czyli podówczas 'dostępny'.

W rozdziale 31 o Protagorasie (jako też w rozdziale odpowiadającym zbiorowi Grahama, oprócz tego w DK) chcielibyśmy znaleźć passusy o dikē huper misthou, czyli dysputę pomiędzy Protagorasem i Euatlosem, która jest zdecydowanie paradygmatycznym przykładem doskonale wyważonej antylogii oraz sytuacji całkiem nierozstrzygalnej i zaskakującej, która została sprowadzona do krótkiej syntezy zawartej u Diogenesa Laertiosa.

Można ponadto zadać pytanie, dlaczego obydwaj autorzy zdecydowali się mówić o „systemach filozoficznych późniejszych” z odniesieniem do 'pluralistów' - do Archelaosa, Diogenesa z Apollonii, tekstów lekarskich i papirusu z Derveni, zważywszy, że nie chodzi ani o systemy, ani o teksty nieodwołalnie filozoficzne, podczas gdy późniejsze od V wieku przed Chr. są tylko niektóre teksty lekarskie (nie wszystkie) oraz ów papirus.

Rozumie się, że uwagi te nie mogą w żaden sposób przyćmić zasług tego dzieła, które nie może nie stanowić tekstu, który od zaraz staje się nieodzowny dla każdego, kto styka się z przedsokratykami (albo lepiej, z przedplatonikami, włączając Sokratesa). Jeśli zaś uwzględnimy 1.06o stron informacji z Die Philosophie der Antike, I, Frühgriechische Philosophie, dzieła opracowanego pod redakcją Flashara, Bremera i Rechenauera (Basel 2013), możemy śmiało powiedzieć, że studia mad przedsokratykami są dziś w stanie oprzeć się na nowych podstawach dzięki możności liczenia się z uwspółcześnionymi, bardzo profesjonalnymi zasobami. 